\title{
The Cornubian geothermal province: heat production and flow in SW England: estimates from boreholes and airborne gamma-ray measurements
}

David Beamish ${ }^{*}$ and Jon Busby

${ }^{*}$ Correspondence:

dbe@bgs.ac.uk

British Geological Survey,

Keyworth, Nottingham NG12

$5 \mathrm{GG}, \mathrm{UK}$

\begin{abstract}
The Cornubian granite batholith provides one of the main high heat production and flow provinces within the UK. An extensive programme of borehole measurements was undertaken in the 1980s to characterise the geothermal resource. Here we revisit the published data on heat flow and heat production from 34 boreholes and revise the published heat flow values in accord with modern palaeoclimate knowledge. This leads to a more rigorous (and increased) set of estimated temperatures at depth across the granite outcrops. Predicted temperatures at a depth of $5 \mathrm{~km}$ largely exceed $20{ }^{\circ} \mathrm{C}$ and are $6-11 \%$ higher than previously estimated values. We also reconsider the borehole heat production values in conjunction with new heat generation information from a recent regional-scale airborne geophysical survey. The radiometric (gammaray) data provide detailed ( $70 \mathrm{~m}$ along-line) ground concentration estimates of the heat-producing radioelements. These are then combined to estimate heat production in the near surface. The airborne estimates are subject to attenuation by the soil profile. Here we demonstrate and then adopt an assumption that the observations of the soilbedrock medium undergo a flux attenuation by a factor of about two compared to the response of the underlying material. The revised estimates are then correlated with their equivalent deeper borehole estimates. Linear regression is then used to correct the shallow airborne estimates to values that are consistent with the deeper borehole determinations. The procedure provides a detailed and extensive mapping of heat production at both on- and off-granite locations across SW England. The Dartmoor and Land's End granite offer the greatest spatial geothermal potential in terms of their intrinsic radionuclide concentrations and associated heat production. District-scale heat production is studied using the airborne data acquired uniformly across conurbations. The analysis identifies the towns of Camborne, Penzance, St. Austell, Redruth and St Ives as having relatively high values $\left(>4 \mu \mathrm{W} \mathrm{m}{ }^{-3}\right)$ within their urban perimeters.
\end{abstract}

Keywords: Cornubian geothermal province, UK, Granite batholith, Heat production, Heat flow, Boreholes, Airborne gamma-ray data

\section{Springer Open}

(c) 2016 Beamish and Busby. This article is distributed under the terms of the Creative Commons Attribution 4.0 International License (http://creativecommons.org/licenses/by/4.0/), which permits unrestricted use, distribution, and reproduction in any medium, provided you give appropriate credit to the original author(s) and the source, provide a link to the Creative Commons license, and indicate if changes were made. 


\section{Background}

The Earth's natural heat is principally derived from the decay of the long-lived radioactive isotopes of uranium, thorium and potassium together with a contribution from heat released during the formation of the Earth's core and interior. At the surface, there is a continuous heat flow comprising the heat flow from the mantle and lower crust supplemented by heat production from the radioactive isotopes which are largely concentrated in the upper crust. The study of heat production and flow is therefore the main tool for the identification and location of geothermal resources. Within the UK, the granite batholith underlying much of SW England has long been regarded as a source of potential geothermal energy (Downing and Gray 1986a, b).

Borehole $(\mathrm{BH})$ assessments form the primary source of heat production and flow information but such measurements are often sparse. Supplementary geological and geophysical information is then incorporated to aid the assessment. Aeromagnetic data have been used in geothermal investigations to estimate basal depths of the Curie point magnetic layer (Abraham et al. 2014) and to assess concealed structure (Maystrenko et al. 2014). Baillieux et al. (2014) report on the use of gravity pseudotomography to study the behaviour of density contrasts, related to increased fracture porosity, at depth. Here we utilise modern high-resolution airborne gamma-ray data which is effectively a shallow technique but which has, in theory, a direct relationship to heat production through the estimation of the radioelement concentrations. Although such data have been used previously in the assessment of heat production particularly in relation to granite terranes (Middleton 2013), we here take into account soil attenuation effects and relate the geophysical estimates to the $\mathrm{BH}$ determinations.

When heat production and flow was first studied in plutons, a surprising linear relationship between surface heat flow and heat production was observed (Lachenbruch 1970). This was explained by an exponential decrease of heat production with depth over a crustal scale. The heat flow field in mainland UK was studied by Richardson and Oxburgh (1979) who noted that belts of relatively high heat flow corresponded to zones of crust enriched in radioactive elements. Using the then available BH data for the UK, the authors confirmed the general linear relationship between heat flow and heat production for crustal materials ranging from granite to low-grade metasedimentary basement. It was found that $q_{\mathrm{o}}$ (heat flow in $\mathrm{mW} \mathrm{m} \mathrm{m}^{-2}$ ) was related to heat production $\left(A_{\mathrm{o}}\right.$ in $\mu \mathrm{W} \mathrm{m}{ }^{-3}$ ) as $q_{\mathrm{o}}=27+16.6 A_{\mathrm{o}}$. This was interpreted as indicating all UK rock types involved in heat production had a crustal scale length of about $16 \mathrm{~km}$ when compared to the 5-11 km reported for high heat flow provinces elsewhere. This was held to reflect the nature of the late Precambrian, and Lower to Upper Palaeozoic tectonic events that distinguish the UK.

Additional results obtained across the Cornubian batholith of SW England, and considered here, were then discussed by Wheildon et al. (1981) and found to be largely uncorrelated across the area. It was suggested that heat flow refraction played a significant role due to the complex 3D form of the batholith. This suggestion was later assessed by Sams and Thomas-Betts (1988) who performed 3D numerical modelling of the heat flow field in the SW. The study confirmed that the surface heat flow pattern is dominated by the 3D form of the batholith with heat refraction due to thermal conductivity 
contrasts enhancing heat flow in the granite and lateral flow of heat caused by heat production contrasts diminishing it.

The potential of geothermal energy systems in the UK was subsequently reviewed by Downing and Gray (1986a, b) and later by Lee et al. (1987) and Barker et al. (2000). The reviews and studies discuss low enthalpy systems in Upper Palaeozoic aquifers and thermal springs together with Mesozoic basins. The principal modifications to the UK mean heat flow of $55 \mathrm{~mW} \mathrm{~m} \mathrm{~m}^{-2}$ are found in association with radiogenic granite intrusions. Barker et al. (2000) note that the mean heat flow in the Cornubian granites of SW England is $117 \pm 8 \mathrm{~mW} \mathrm{~m}^{-2}$ compared with maximum values of 101 and $76 \mathrm{~mW} \mathrm{~m}^{-2}$ in the Caledonian granites of northern England and the Grampians of eastern Scotland, respectively. The hot dry rock (HDR) geothermal energy programme carried out in SW England is discussed in the references already cited and is summarised by Richards et al. (1991). The main Camborne School of Mines (CSM) HDR project was carried out between 1977 and 1988. Heat production values obtained in the two main reports by Wheildon et al. (1981) and by Thomas-Betts et al. (1989) are used here.

The locations of the heat production and heat flow results obtained by the CSM project are shown in Fig. 1. The locations are shown in relation to 1:250k mapping of the granite outcrop (in grey) and contours of the subsurface form of the underlying batholith. The

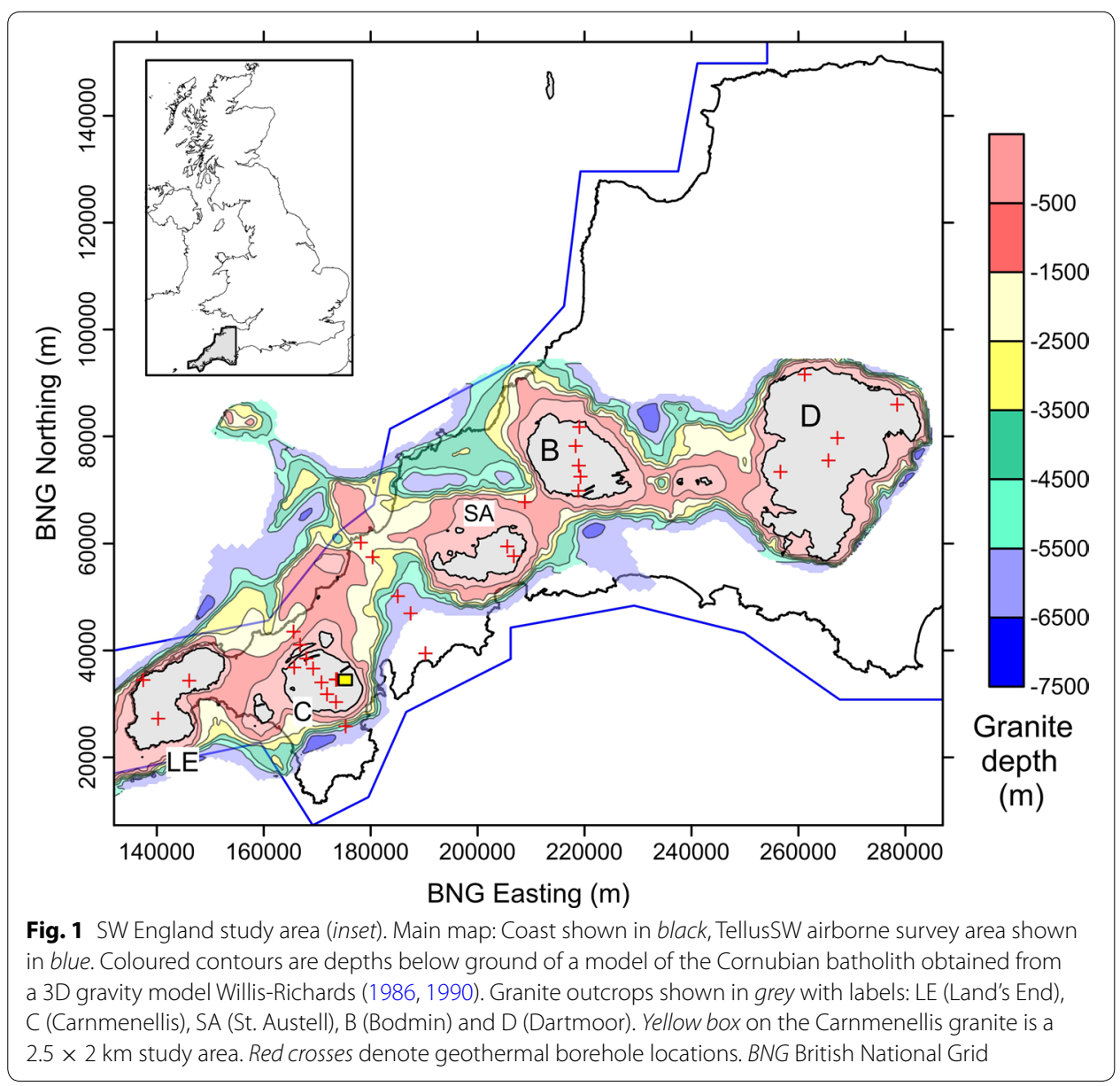


3D form of the batholith, to a depth of $7.5 \mathrm{~km}$, is taken from a 3D gravity model presented by Willis-Richards $(1986,1990)$. The model assumes a single density contrast for the batholith and follows the earlier 3D model of the space form of the granite discussed by Tombs (1977).

Also shown in Fig. 1 is an outline of the extent of a recent high-resolution airborne geophysical survey (TellusSW) that acquired over 61,000 line-km of data, incorporating both aeromagnetic and radiometric (gamma-ray) measurements at 200-m line intervals. The latter data provide estimates of ground concentrations of the three main radionuclides potassium, thorium and uranium used in the estimation of heat production. It is therefore theoretically possible to compare heat production values obtained in boreholes with those obtained by the geophysical survey (both use the same formula based on the radionuclide concentrations). The $\mathrm{BH}$ results, although sparse, were largely obtained at depths of less than $100 \mathrm{~m}$ and therefore represent shallow bedrock determinations and are subject to a degree of vertical variability. The airborne measurements, although spatially uniform and dense, represent very near-surface determinations (e.g. typically less than $0.6 \mathrm{~m}$ ) and are influenced by a variety of near-surface effects principally those relating to soils and water. Previous studies of estimating heat production using airborne radiometric data have generally assumed that the airborne concentration estimates are representative of bedrock (Bodorkos et al. 2004; Middleton 2013; Phaneuf and Mareschal 2014). Since theory predicts flux attenuation effects in all soils, we discuss these effects, particularly in relation to the UK soils. Noting the existence of studies of these attenuation effects (Beamish 2013), we here demonstrate and then adopt an assumption that the observations of the soil-bedrock medium undergo a flux attenuation factor of about two compared to the response of the underlying material (superficial or bedrock) in the absence of soil.

A key parameter in exploring for geothermal resources is the temperature at depth. In situations where heat flow is not perturbed by convection, but is due to near-vertical heat conduction, subsurface temperatures can be estimated from knowledge of surface heat production and heat flow. The locations of on-granite borehole measurements of heat flow are shown in Fig. 1 and were reported by Wheildon et al. (1981). Due to resource limitations, the majority of boreholes were only $100 \mathrm{~m}$ deep. It was recognised that this could cause problems due to ground water flow, deep weathering and recent climate change. These data were supplemented by measurements in mines at South Crofty and Geevor, where access to much greater depths was possible (Tammemagi and Wheildon 1974). These combined results were published in summaries of the UK heat flow (Lee 1986; Lee et al. 1987) and it is these publications which have been widely cited when referencing these data. However, as reported by Lee (1986) and Lee et al. (1987) only a correction for recent climate change was applied, and this was only for boreholes less than $200 \mathrm{~m}$ deep, despite the fact that Wheildon et al. (1981) had undertaken a full palaeoclimate correction. This has led to later criticism (e.g. Westaway and Younger 2013) that the lack of full palaeoclimate-corrected heat flow will have led to an underestimate of temperatures at depth. In the work presented here, the raw heat flow data are reassessed and then corrected for topography and palaeoclimate, using the latest reconstruction of climate from the last glacial cycle, from which new estimates of temperatures at depth are made. 
Heat production values rely only on measurements of the main heat-producing radionuclides. The heat production values obtained as part of the CSM-HDR programme are revisited and compared with the radiometric data from the airborne geophysical survey. Both sets of data are subject to uncertainties; however, by correlating the two sets of estimates (specifically those available at on- and off-granite locations), we are able to adjust the near-surface airborne estimates to be consistent with the deeper BH determinations. These corrected airborne estimates are then used to evaluate heat production across the survey area, across the five main granite outcrops and, in more detail, within urban centres. The latter is informative in relation to a consideration of the degree to which the high-spatial resolution estimates of the radionuclide concentrations can be incorporated in district-scale assessments of heat production.

\section{Methods}

\section{Heat flow}

Heat flow is not directly measured, but is calculated from a measured vertical temperature gradient that is combined with the thermal conductivity of the strata over which the temperature gradient was measured. A re-examination of the temperature data from the borehole sites has indicated poor-quality temperature logs resulting in erratic temperature gradients for Medlyn farm (C-C), Soussons wood (D-C) and Hemerdon (H) and these are therefore not considered further in relation to heat flow. The two mine sites (South Crofty: SCM and Geevor: GM) both produce anomalously high heat flows. Tammemagi and Wheildon (1974) report that the temperature measurements were made in horizontal and inclined boreholes at various levels throughout the mines. They discussed the possibility that the extensive period of mining would have led to disturbed temperatures in the mine that might have affected virgin rock temperatures. In their opinion, at borehole depths of greater than $43 \mathrm{~m}$, there should have been no noticeable effect. However, the data here suggest that mining activity has most likely affected temperature gradients and these two mine sites do not reflect purely conductive heat flow and are therefore also not considered further. Heat production values for the sites are however used.

The remaining, on-granite, heat flow determinations have been subjected to a full palaeoclimate and topographic correction. Past climate variations perturb temperature gradients in the ground from which heat flow is calculated. Palaeoclimate can be considered as a series of one off-surface temperature changes that propagate into the ground and their effect depends on the magnitude of the change in surface temperature and the time that has elapsed since the change. A surface temperature history for the Quaternary consists of a series of cyclical (e.g. glacial-interglacial cycles) changes in temperature between warmer and colder conditions. Each cycle can last from a few hundred to several thousand years. The surface temperature history applied for the correction is shown in Fig. 2. It comprises a record from 126 kyr BP (Before Present) reported by Busby et al. (2016) for SW England with a modification for recent climate. The recent climate record is as follows:

- a mid-Holocene climate optimum of $+1.5^{\circ} \mathrm{C}$ between 7 and $3.5 \mathrm{kyr} \mathrm{BP}$,

- medieval warm period of $+0.8^{\circ} \mathrm{C}$ between 1 and $0.7 \mathrm{kyr} \mathrm{BP}$, 


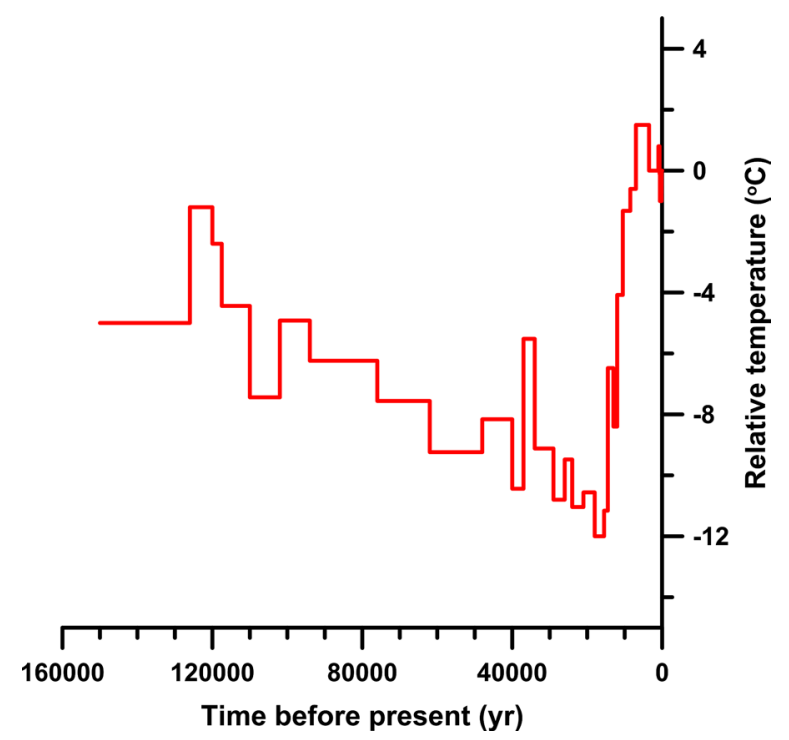

Fig. 2 Estimated surface temperature history for SW England based on a palaeoclimate reconstruction presented by Busby et al. (2016) but modified for recent climate change. Temperatures are relative to present day

- Little Ice Age of $-1.0{ }^{\circ} \mathrm{C}$ between 0.6 and $0.15 \mathrm{kr}$ BP (but introduced in two equal steps at 700 and 600 years ago) and

- return to present-day temperatures with 4 equal steps of $0.25{ }^{\circ} \mathrm{C}$ between 150 and 120 years ago.

The correction to subsurface temperatures due to the palaeoclimate record uses standard procedures (e.g. Beck 1977; Beardsmore and Cull 2001; Westaway and Younger 2013) and heat flow is then recalculated from the corrected temperature gradients. Topographic corrections are positive for hill-based localities and negative for valleys and those from Wheildon et al. (1981) have been applied here. Table 1 lists the heat flow from Lee (1986) that included a palaeoclimate correction for recent climate only, raw heat flow (calculated in this study), the full palaeoclimate correction (calculated in this study), the topographic correction (from Wheildon et al. 1981) and the revised heat flow (HF REV) which is the sum of the raw heat flow, the full palaeoclimate correction and the topographic correction.

\section{Heat production}

Heat production measurements within the CSM project were carried out by evaluating the uranium, potassium and thorium concentrations in crushed core samples by gamma-ray spectroscopy. Heat production was then calculated from the loss of mass produced by decay, except the amount carried away by the neutrino, since all energy is converted to heat in the immediate vicinity of the decaying nucleus (Rybach 1973). The primary heat production is considered to take place from the alpha and beta particle emissions from uranium (Rybach 1976, 1988).

The constants used in the conversion by Wheildon et al. (1981) were obtained from Rybach (1973) and were stated to be 96.6 (uranium), 25.7 (thorium) and $3.49 \times 10^{-3}$ 


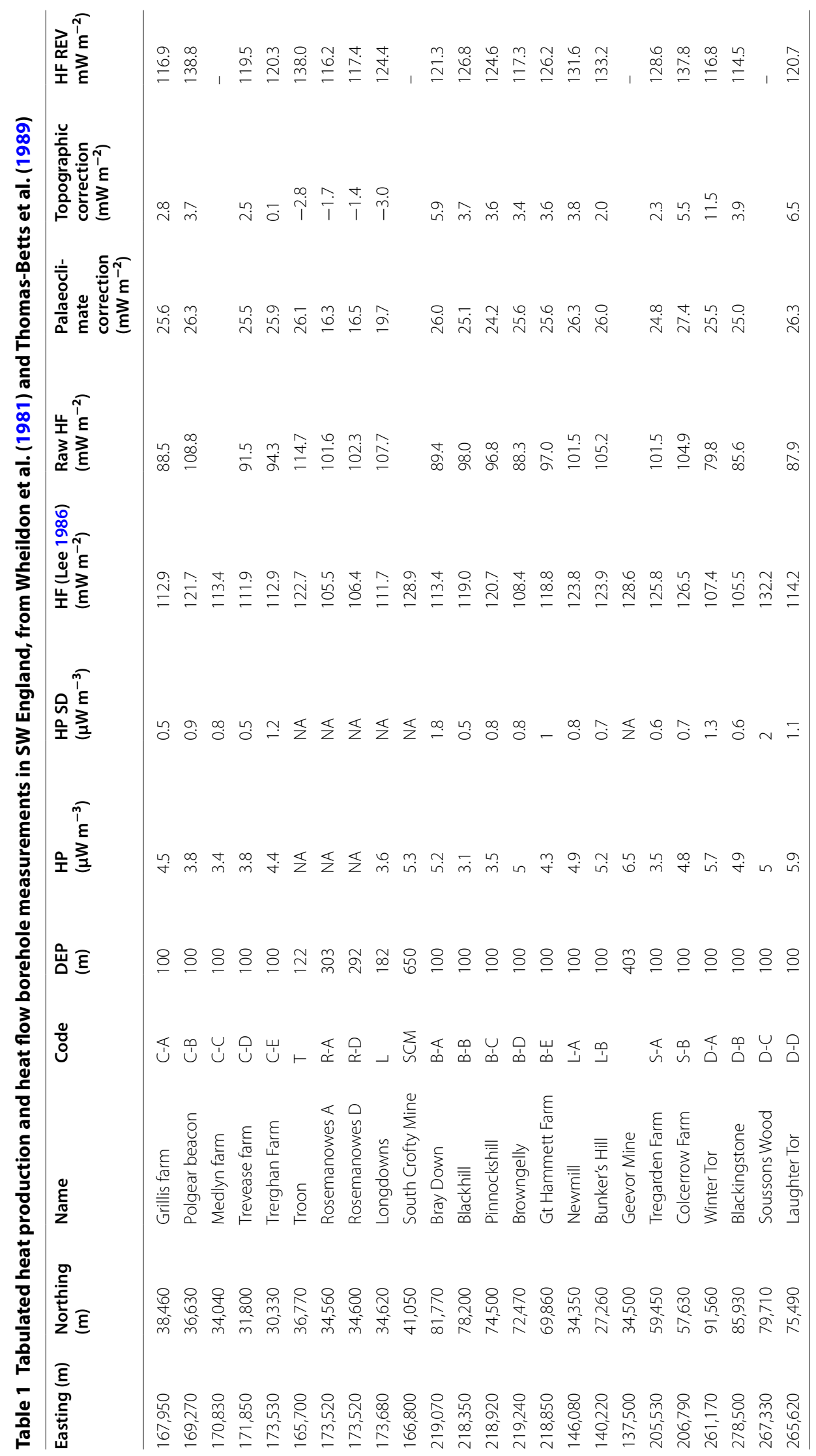




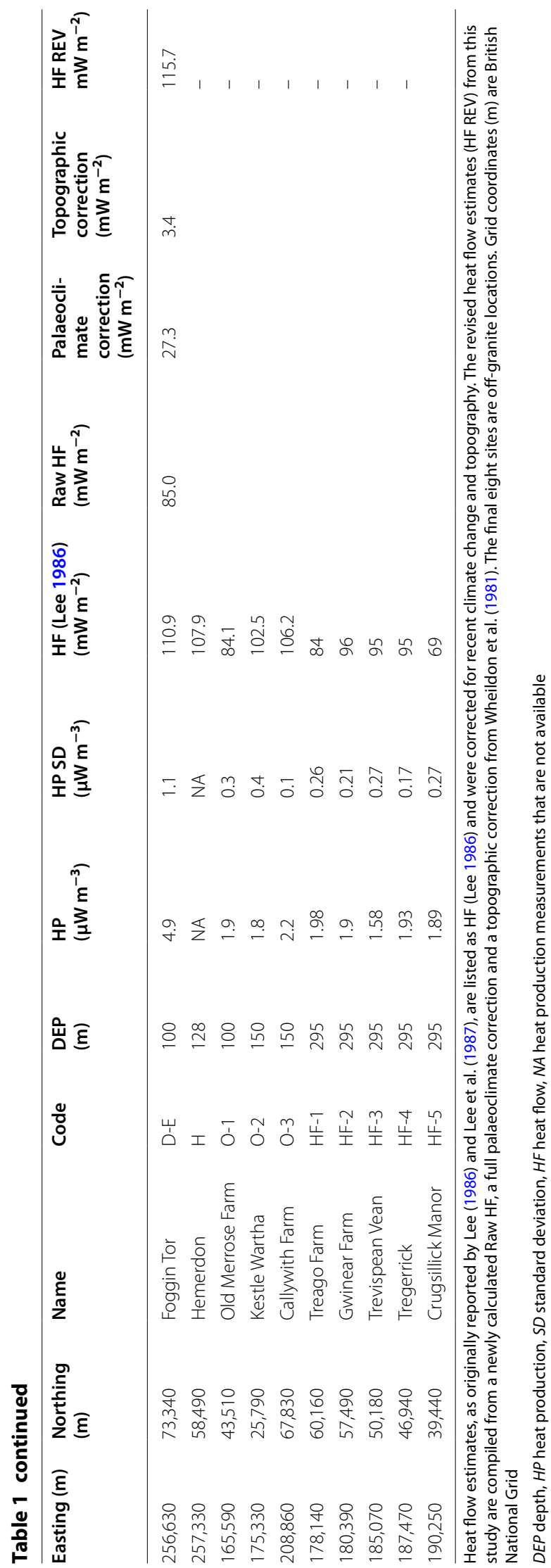


(potassium) with no units given. From Rybach (1988), we find a more complete description of the units with a slight modification to the constants. Using practical radioelement concentrations by weight $(C)$ of uranium $\left(C_{\mathrm{U}}, \mathrm{ppm}\right)$, thorium $\left(C_{\mathrm{Th}}, \mathrm{ppm}\right)$ and potassium $\left(C_{\mathrm{K}}, \%\right)$, the radioactive heat production in $\mathrm{W} \mathrm{m} \mathrm{m}^{-3}(\mathrm{H})$ is given as

$$
H=10^{-5} \rho\left(9.52 \times C_{\mathrm{U}}+2.56 \times C_{\mathrm{Th}}+3.48 \times C_{\mathrm{K}}\right),
$$

where the rock density $(\rho)$ in $\mathrm{kg} \mathrm{m}^{-3}$ was obtained from the core samples. Equation (1) has been used extensively in the geothermal literature (e.g. Maystrenko et al. 2014) and is used here to (i) provide our final (revised) estimates of heat production from the airborne data and taking into account rock densities.

It is also worth noting that heat production formulae, not requiring specific use of the rock density, have also been applied in the geophysical literature (Jessop 1990; Brady et al. 2006). Middleton (2013) indicates heat production $A$ in units of $\mu \mathrm{W} \mathrm{m}{ }^{-3}$ which can be obtained as

$$
A=0.26 \times C_{\mathrm{U}}+0.07 \times C_{\mathrm{Th}}+0.10 \times C_{\mathrm{K}}
$$

with the concentrations $(C)$ as defined previously. Comparing concentration coefficients in (1) and (2), we find that Eq. (2) assumes an equivalent density of $2.73 \mathrm{~g} \mathrm{~cm}^{-3}$ (uranium), $2.73 \mathrm{~g} \mathrm{~cm}^{-3}$ (thorium) and $2.87 \mathrm{~g} \mathrm{~cm}^{-3}$ (potassium). These values compare with density estimates of the Cornubian granites of $2.58-2.67 \mathrm{~g} \mathrm{~cm}^{-3}$ and non-granite densities from 2.48 to $2.99 \mathrm{~g} \mathrm{~cm}^{-3}$ [the latter high value is from the ultrabasic Lizard complex (Tombs 1977)]. Noting this approximate correspondence, we provide an example of the use of Eq. (2) but use Eq. (1) for our final (revised) estimates of heat production. Both equations are empirical.

\section{Airborne radiometric data}

The majority of the TellusSW survey (see Fig. 1) was flown in the latter half of 2013. The 61,000 line- $\mathrm{km}$ of data and the processing undertaken are described by Beamish and White (2014). The survey used a N-S line separation of $200 \mathrm{~m}$ and a radiometric data sampling of $1 \mathrm{~Hz}$ providing an along-line sampling of $71 \mathrm{~m}$. The survey achieved a mean flying elevation of $92 \mathrm{~m}$ from a nominal elevation of $80 \mathrm{~m}$. The radiometric data were acquired with a 256-channel gamma spectrometer system (GeoExploranium GR-820/3) comprising 321 of downward-looking $\mathrm{NaI}(\mathrm{Tl})$ detectors and 81 of upwardlooking detectors. Uranium $\left({ }^{238} \mathrm{U}\right)$ is estimated through the radon daughter ${ }^{214} \mathrm{Bi}$ in its decay chain, while thorium $\left({ }^{232} \mathrm{Th}\right)$ is estimated through ${ }^{208} \mathrm{Tl}$ in its decay chain. Potassium $\left({ }^{40} \mathrm{~K}\right)$ is measured directly at $1.461 \mathrm{MeV}$. Conventionally secular equilibrium in the decay chains of uranium and thorium is assumed (Minty 1967) and the ground concentration results are reported as equivalent uranium (eU, $\mathrm{ppm})$ and equivalent thorium (eTh, ppm). Potassium is reported as \%K. A vertically uniform activity concentration is assumed.

The gamma radiation registered by the detector is composed of contributions from soil/rock, the atmosphere, the aircraft and cosmic radiation. In order to calibrate airborne radiometric data, the commonly adopted standard is to follow the recommendations made in a series of technical documents and publications from the International 
Atomic Energy Agency (IAEA). The set of procedures applied here is based on protocols described in IAEA (1991, 2003, 2010) and by Grasty and Minty (1995).

The field of view of the airborne system is a significant factor in terms of the resolution of material property boundaries. The field of view depends on survey altitude and is also a complex spatial function, peaking below the airborne receiver when the flux source can be considered an isolated body. The ground area or footprint, which contributes radioactivity to each 1-s measurement, was assessed by Pitkin and Duval (1980). For a stationary measurement, at a height of $60 \mathrm{~m}, 90 \%$ of the airborne response will be provided across a circle of radius 160-180 m (Kock and Samuelsson 2011).

\section{Results}

Heat flow

Recalculated heat flows, corrected for palaeoclimate and topography, are shown in Table 1; as explained previously, the values from Medlyn Farm, Soussons Wood, Hemerdon, South Crofty and Geevor are no longer considered valid. The magnitude of the full palaeoclimate correction depends on the depth sections in the boreholes from which heat flow was calculated. For the shallow boreholes (depth $100 \mathrm{~m}$ ), the correction ranges from 27.4 to $24.2 \mathrm{~mW} \mathrm{~m}{ }^{-2}$, whilst for the three deeper boreholes (Rosemanowes A, $\mathrm{D}$ and Longdowns) it ranges from 19.7 to $16.3 \mathrm{~mW} \mathrm{~m}^{-2}$. Compared to the heat flows reported by Lee (1986) and Lee et al. (1987), which were only corrected for the effects of recent climate in boreholes less than $200 \mathrm{~m}$ deep, there is an increase in all values ranging from $2.8 \mathrm{~mW} \mathrm{~m}^{-2}$ at Tregarden Farm to $17.1 \mathrm{~mW} \mathrm{~m}^{-2}$ at Polgear Beacon.

The fully corrected heat flows and borehole-derived heat production data, as listed in Table 1, have been used to estimate temperatures at $5 \mathrm{~km}$ depth for each of the granites. Solutions for calculating the subsurface temperature are given by Wheildon et al. (1981) and Wheildon and Rollin (1986). These take into account the decrease of thermal conductivity with increasing temperature, which will occur with increasing depth, i.e.

$$
\lambda_{z}=\frac{\lambda_{0} a^{\prime}}{\left(b^{\prime}+T_{z}\right)}
$$

where $\lambda_{z}\left(\mathrm{~W} \mathrm{~m} \mathrm{~m}^{-1} \mathrm{~K}^{-1}\right)$ is the thermal conductivity at depth $z(\mathrm{~km}), \lambda_{0}\left(\mathrm{~W} \mathrm{~m}^{-1} \mathrm{~K}^{-1}\right)$ is the surface thermal conductivity, $T_{z}\left({ }^{\circ} \mathrm{C}\right)$ is the temperature at depth $z, b^{\prime}$ is an empirical constant, with units of ${ }^{\circ} \mathrm{C}$, quoted by Wheildon and Rollin (1986) as 823.33 and $a^{\prime}=b^{\prime}+T_{0}$ (where $T_{0}$ is the surface temperature in ${ }^{\circ} \mathrm{C}$ ). The vertical temperature distribution is given by Wheildon and Rollin (1986) as

$$
T_{z}=a^{\prime} \mathrm{e}^{\frac{\left(q_{0} z-f(z)\right)}{a^{\prime \prime} 0}}-b^{\prime}
$$

where $q_{0}\left(\mathrm{~mW} \mathrm{~m}^{-2}\right)$ is the surface heat flow. In accordance with Lee et al. (1987), it is assumed that there is constant heat production with depth, in which case $f(z)$ in Eq. (4) has the form:

$$
f(z)=\frac{A_{0} z^{2}}{2}
$$




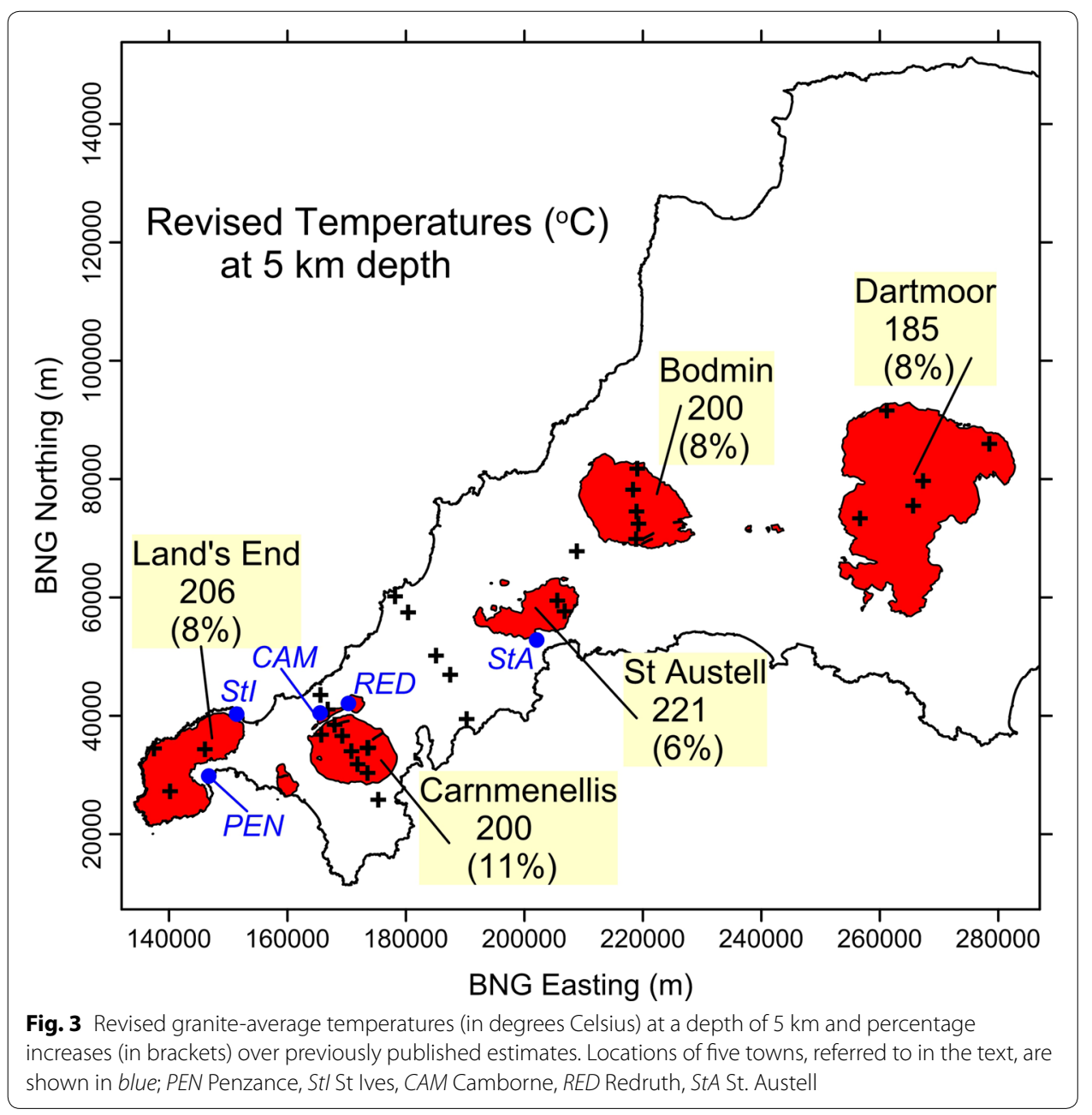

where $A_{0}\left(\mu \mathrm{W} \mathrm{m}{ }^{-3}\right)$ is the surface heat production. The temperatures at $5 \mathrm{~km}$ depth are shown in Fig. 3 and range from $185{ }^{\circ} \mathrm{C}$ for the Dartmoor granite to $221{ }^{\circ} \mathrm{C}$ for the St. Austell granite. This represents increases from 6 to $11 \%$ for $5-\mathrm{km}$ depth temperatures compared to temperatures calculated with the heat flow values reported by Lee (1986) and Lee et al. (1987). The only deep temperature measurements were in the HDR boreholes at Rosemanowas quarry. Barker et al. (2000) report temperatures of $79^{\circ} \mathrm{C}$ at $2.1 \mathrm{~km}$ depth in well RH 12 and $100{ }^{\circ} \mathrm{C}$ at $2.6 \mathrm{~km}$ depth in well RH 15. The revised heat flow for the average of Rosemanowas A and D is $116.8 \mathrm{~mW} \mathrm{~m}^{-2}$, which, with the constant heat production with depth model, gives subsurface temperatures of $84.3{ }^{\circ} \mathrm{C}$ at $2.1 \mathrm{~km}$ depth and $102.0^{\circ} \mathrm{C}$ at $2.6 \mathrm{~km}$ depth, slightly higher than the measured temperatures.

\section{Heat production}

The heat production values shown in Table 1 are averages (mean values and standard deviations) over an ensemble (about 10-15) of core samples taken from each exploration borehole. At on-granite sites (i.e. those on the outcrop), the depth interval was largely in the range from 6 to $100 \mathrm{~m}$. For the off-granite sites HF-1 to HF-5, the samples were obtained from the depth interval from 100 to $200 \mathrm{~m}$. The values represent a vertical 


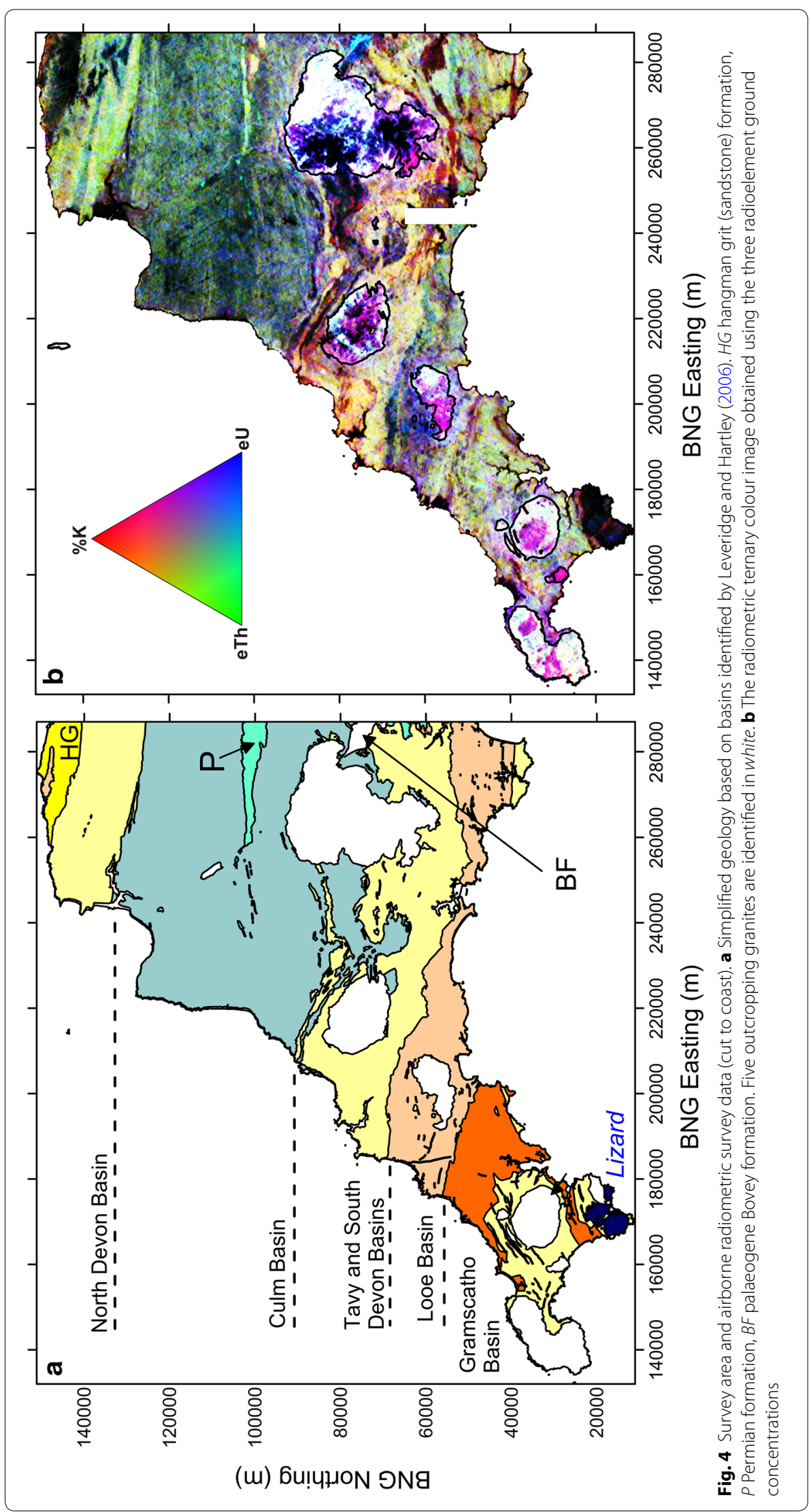


average of the heat production due to the bedrock radionuclides over the depth ranges indicated. In order to compare the borehole results with equivalent values obtained by the airborne data, the latter must be converted to 'bedrock-equivalent' values.

The airborne survey radiometric data are displayed as a ternary image alongside a simplified version of the bedrock geology in Fig. 4. The granites intruded the existing country rock during the Variscan Orogeny producing metamorphic zones and establishing the fluid circulation responsible for the extensive metalliferous mineralisation of the region (Dines 1956). The majority of the metasediments are pelites or greywackes and are of Devonian age although a large, originally extensional structure preserved Carboniferous sediments as the Culm Basin (Fig. 4a). Following Leveridge and Hartley (2006), a sequence of basins is identified in Fig. 4a to allow comparison with the radiometric data.

The ternary image (Fig. 4b) is a three-way colour stretch formed from the distributions of potassium (red), thorium (green) and uranium (blue). The image is cut to coast to remove the null responses over the offshore area. White responses indicate areas in which all three radioelements have high concentrations, while black responses represent low concentrations. The zones with the highest radiometric responses are associated with, and largely confined to, the outcropping granite zones. Within the granite outcrops, areas of preferential potassium enrichment are observed. It is worth noting that the radiometric data across the Bodmin granite have identified a previously unknown internal edge, clearly defined by high values, within the outcrop. Low-value responses occur in association with the ultramafic Lizard ophiolite complex and, in the north, with a Devonian lithology named the Hangman Grit (HG) sandstone formation which has a specific deltaic origin. Other contrasting response characteristics are observed with the Permian (P) lithologies associated with the Crediton Trough and the Palaeogene Bovey Formation (BF) in the east.

Comparing Fig. $4 \mathrm{a}, \mathrm{b}$, it is evident that, at the large scale shown, the bedrock formations control the spectral response (colour) of the radiometric data. Within this framework, many other detailed variations are observed. Within the Bodmin and Dartmoor granites, low responses are caused by significant areas of peat formed on the high ground (moors) above the granites. The largest area of attenuation is due to blanket bog covering the majority of the western portion of the Dartmoor granite. In order to fully understand the radiometric response observed 'in-air', either by ground or airborne surveys, the role of both soils and bedrock must be considered.

The conceptual model of soil-bedrock behaviour is that the bedrock acts as a parent material to the soil so that the particle size, mineralogy and radiochemistry of the soil derive from the bedrock material. In areas where soil material transport takes place (e.g. erosion), the model may no longer be appropriate. When the data are examined in relation to a detailed DTM, a limited amount of radionuclide transport may be deduced such as that occurring at the western end of the Permian inlier (P, Fig. 4a) which has a strong thorium response. Uniform concentrations of radioelements with depth are necessarily assumed when non-invasive measurements are made.

\section{Soil effects}

The observed in-air response will be derived from a given radiometric source concentration (assumed vertically uniform in the first instance) that is primarily obtained from a 
shallow subsurface zone (often $<0.6 \mathrm{~m}$ ). Exponential absorption characterises the passage of electromagnetic radiation through a homogenous material with a mass attenuation coefficient controlling the decay scale length. Løvborg (1984) indicates that all elements with an atomic number less than 30 will have comparable mass attenuation coefficients. In the absence of water and soil, superficial and bedrock materials will have comparable attenuation coefficients at a given source concentration. Attenuation in dry materials is therefore controlled by density alone. This has given rise to the concept that about $90 \%$ of the radiometric flux comes from the top $30 \mathrm{~cm}$ of a soil when the average bulk density is $1.6 \mathrm{~g} \mathrm{~cm}^{-3}$ (Beamish 2015). Additional attenuation effects are introduced when the material contains water (Løvborg 1984; Grasty 1997). The additional sensitivity of wet soil was investigated by Beamish (2013,2014a) who provides a set of exponential decay curves as a function of soil type (e.g. density) and degree of saturation. Generally, the attenuation behaviour of total flux from the subsurface is controlled by soil properties (joint density, wetness) in the upper $50-60 \mathrm{~cm}$ of the soil profile.

It is possible to compare the airborne ground concentration estimates (obtained 'inair' and representing a large surficial area) with radioelement concentrations obtained by point-located, field geochemical sampling and subsequent laboratory analysis. Beamish (2014a) undertook a geostatistical assessment of these relationships for the large airborne and soil sampling (5-20 cm depth) survey of Northern Ireland (Beamish and Young 2009). The analysis, involving a comparison of 6862 samples, indicated a quasilinear relationship between the two sets of estimates with the soil estimates providing persistently higher values. A similar analysis for the airborne and ground geochemical data available for the present study area (775 ground sample points) again reveals a clear bias to higher values in the ground (laboratory) estimates with statistically determined average increases of 1.9 (potassium), 1.3 (thorium) and 1.7 (uranium) with respect to the airborne estimates.

In the absence of detailed knowledge of the near-surface behaviour of the soil-derived flux decay, we assume that the soil profile is everywhere sufficiently thick (e.g. $>50-$ $60 \mathrm{~cm}$ ) to account for the same attenuation of the flux at depth (i.e. the flux that would be observed from uniform bedrock alone). This is inevitably a simplification but the supporting information suggests a factor of between 1.3 and 1.9. To illustrate the effect, we have chosen a $2.5 \times 2 \mathrm{~km}$ area on the Carnmenellis granite (see Fig. 1) which has uniform bedrock and largely uniform soils derived from the underlying weathered granite (freely draining acid loam soils). A background topographic map of the area is shown in Fig. 5a. There are a number of granite quarries indicated and these can be more clearly identified in the aerial photograph shown in Fig. 5b. The three quarries identified (Q1Q3) are assumed to have large areas of either no soil cover or partially very thin soils. The airborne sampling of these areas is clearly limited by the $200 \mathrm{~m}$ line spacing. The total count airborne data, a measure of the total flux across the energy range from 0.404 to $2.805 \mathrm{MeV}$, are contoured in Fig. 5c. The background soil-bedrock response appears to lie in the range from 2000 to $2500 \mathrm{cps}$ with the highest values observed across the two larger quarries. The central locations of the main Q1 and Q2 quarries are associated with values in the interval from 3500 to $4000 \mathrm{cps}$. Despite the detailed complexities of the broader area (small water bodies and conurbations), the main influence on the amplitude of the flux appears to be the presence or absence of soil cover. A factor of two 


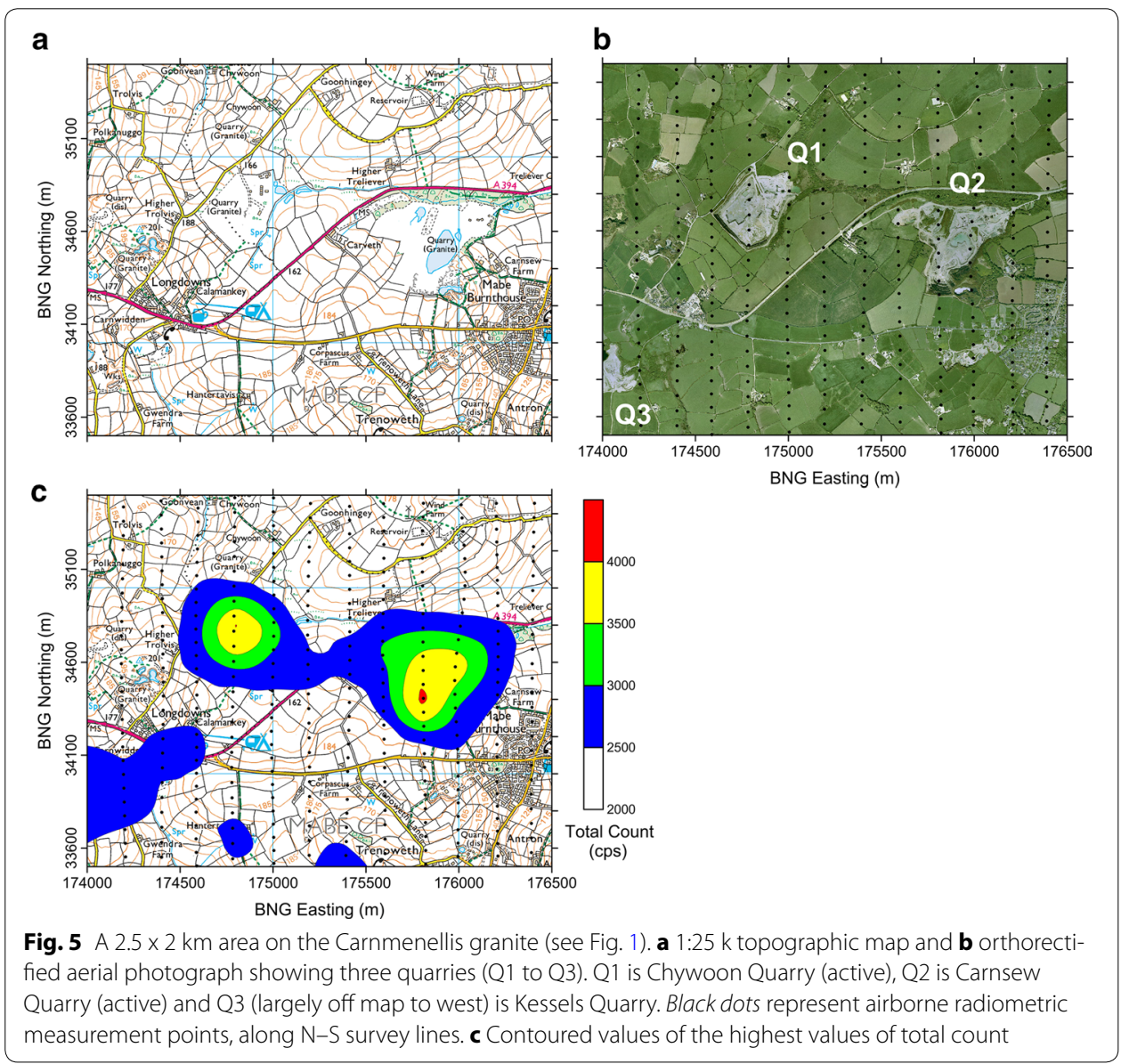

increase in the airborne estimates appears to be a reasonable 'simplified' estimate of the soil effect in this case. Other supporting information obtained across large quarries is provided by Beamish (2014b).

In order to provide estimates of heat production due to near-surface bedrock, using Eqs. (1) and (2), we therefore multiply the estimated ground concentrations (eTh, eU and $\% \mathrm{~K})$, in Eqs. (1) and (2), by a factor of 2 . The value of 2 used is simply a 'rounded' estimate when actual values may vary spatially between 1 and 2 (e.g. between 1.3 and 1.9 as determined statistically above). We use the value of 2 since the actual value is imprecise and adopt a simplified uniform approach. The one soil type that remains problematic is peat which is a non-mineral, organic material with very low density and high water content (e.g. $>80 \%$ volumetric). Peat, typically found in extensive areas of blanket bog, is found to provide a response that is close to that of water and the total flux observed may be zero or close to the noise level of the data (see Fig. 3b). The presence of peat therefore masks assessments of the radiometric character of the underlying materials.

\section{Revised heat production}

Figure 6 shows the values of heat production estimated using Eq. (2) and incorporating the factor of two. The image is based on a grid cell size of $500 \mathrm{~m}$ which reduces localscale variability and areas of blanket bog are omitted. It is evident that the highest heat 


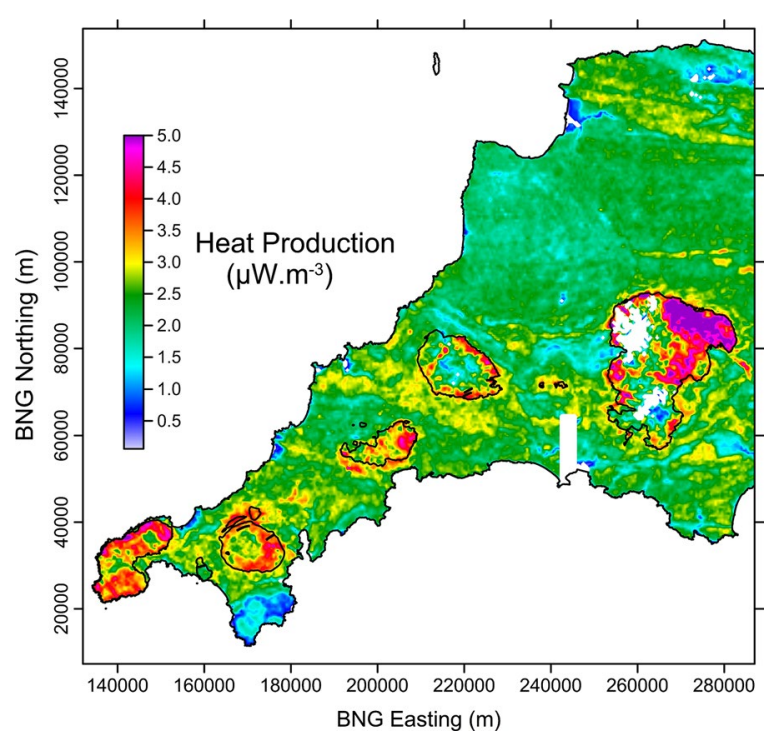

Fig. 6 Revised heat production estimates obtained using Eq. (2). Black lines denote granite outcrops. White areas denote areas of blanket bog

production values (e.g. $>4 \mu \mathrm{W} \mathrm{m}{ }^{-3}$ ) are associated with the granites, particularly their perimeters. The highest, spatially sustained values are observed across the NE of the Dartmoor granite. The values obtained have been compared with their much deeper borehole counterparts listed in Table 1 . The BH point locations were buffered by circles with radii ranging from 100 to $250 \mathrm{~m}$. The statistical behaviour of the airborne estimates falling within these zones was then examined. It was found that a buffer radius of $200 \mathrm{~m}$ provided between 9 and 15 airborne estimates per BH sampling zone. The median value is used in the comparison.

The set of three individual radionuclide and heat production estimates (Eq. 2) are compared in Fig. 7. The error bars are tabulated standard deviations from the BH estimates of Table 1 and published in Wheildon et al. (1981) and Thomas-Betts et al. (1989). The off-granite locations are identified using red symbols. The three radionuclides display different behaviour. In the case of potassium and uranium (Fig. 7a, c, respectively), ongranite locations display $\mathrm{BH}$ estimates greater than the airborne estimates. In the case of thorium (Fig. 7b), all locations tend to provide BH estimates less than the airborne estimates. When it comes to providing an estimate of heat production using Eq. (1) or (2), the behaviour of the uranium estimates provides the highest weighting.

The heat production estimates shown in Fig. $7 \mathrm{~d}$ use the $\mathrm{BH}$ values shown in Table 1 and airborne estimates obtained using Eq. (1) and the previously noted factor of 2 . The granite density used was $2.63 \mathrm{~g} \mathrm{~cm}^{-3}$ (an average across the 5 granites) and the off-granite density used was $2.73 \mathrm{~g} \mathrm{~cm}^{-3}$ which is equivalent to assuming a uniform density contrast of $0.1 \mathrm{~g} \mathrm{~cm}^{-3}$ across the study area. The behaviour observed in Fig. $7 \mathrm{~d}$ shows a clear distinction between on- and off-granite locations. The causes of the behaviour are not known; however, we wish to provide best estimates of the heat production associated with the deeper bedrock. On this basis, it is possible to correct the airborne estimates by establishing corrections for the on- and off-granite sites, separately. Figure $7 \mathrm{~d}$ shows two 

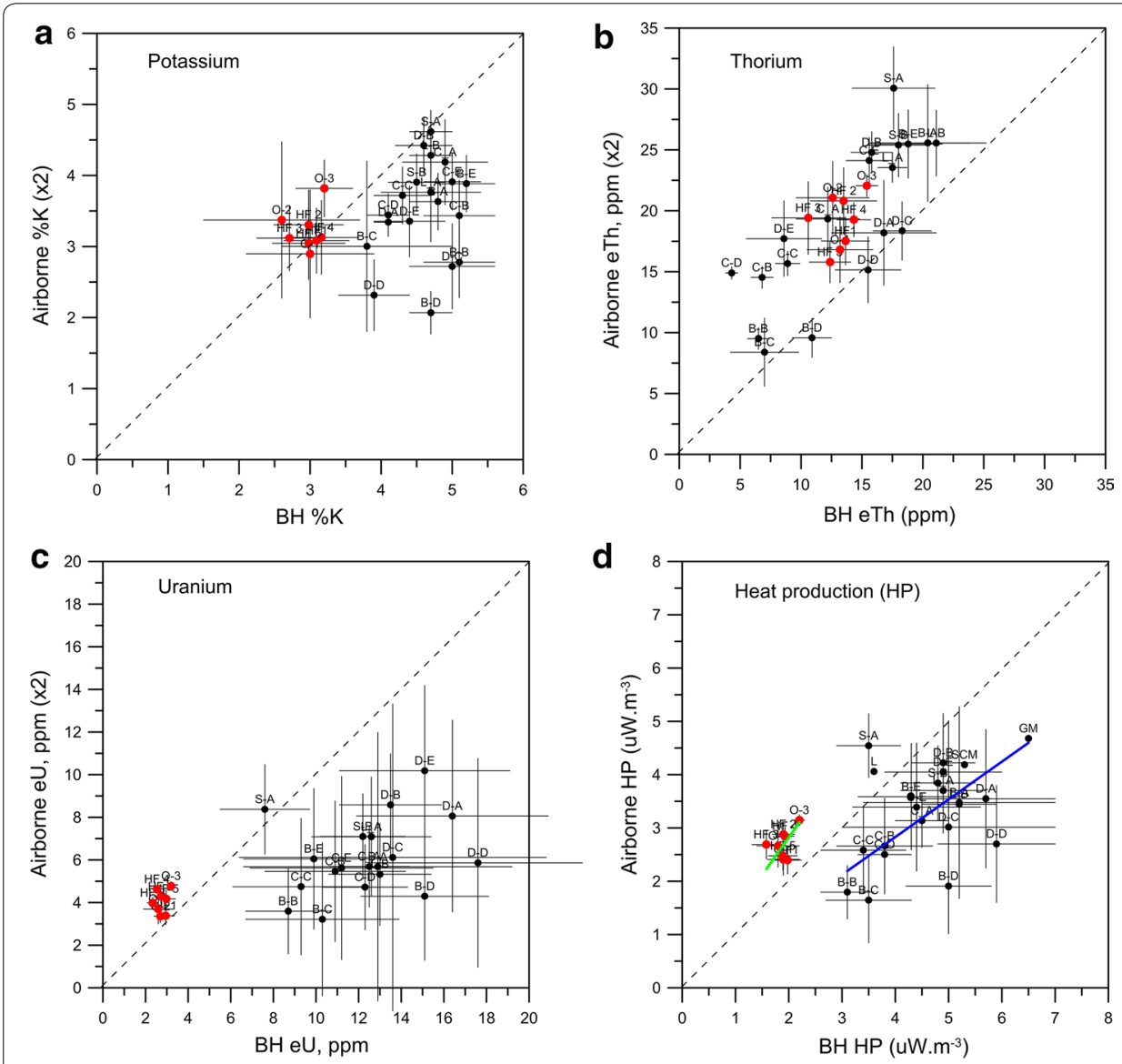

Fig. 7 a-c Comparison of borehole $(\mathrm{BH})$ and airborne radionuclide concentration estimates for a potassium, b thorium and $\mathbf{c}$ uranium. Red symbols denote off-granite locations. Error bars are taken from the BH measurements and denote 1 standard deviation. d Corresponding comparison for heat production. Green line denotes best linear fit for off-granite locations and blue line denotes the corresponding fit for on-granite locations. BH codes are those listed in Table 1

linear fits obtained in this way. On the basis that the linear fit must pass through the origin, we find that on-granite airborne estimates must increase by a factor of 1.41 and the off-granite estimates must decrease by a factor of 0.88 , to be consistent with the deeper $\mathrm{BH}$ estimates. The linear fits shown in Fig. $7 \mathrm{~d}$ have coefficients of determination $\left(R^{2}\right)$ of 0.94 for the granite locations and 0.99 for the off-granite locations. The heat production estimates obtained in this way [i.e. (i) applying a multiplication factor of 2 in relation to the airborne ground concentrations, (ii) using Eq. (2) and then (iii) applying the linear fits to the $\mathrm{BH}$ heat production values] are referred to as $\mathrm{BH}$-corrected values.

\section{$\mathrm{BH}$-corrected heat production}

At the large scale, the $\mathrm{BH}$-corrected heat production estimates (shown later) follow the same distribution pattern shown in Fig. 6 . Here we are primarily interested in the high heat production associated with the granites and their margins. The areal extent of granite outcrops was radially buffered by a length of $2 \mathrm{~km}$ and the airborne results were examined in detail. Here we provide an example using the Carnmenellis granite $(C$ in Fig. 1). Figure 8 first summarises the known granite structure (1:50k bedrock mapping) 


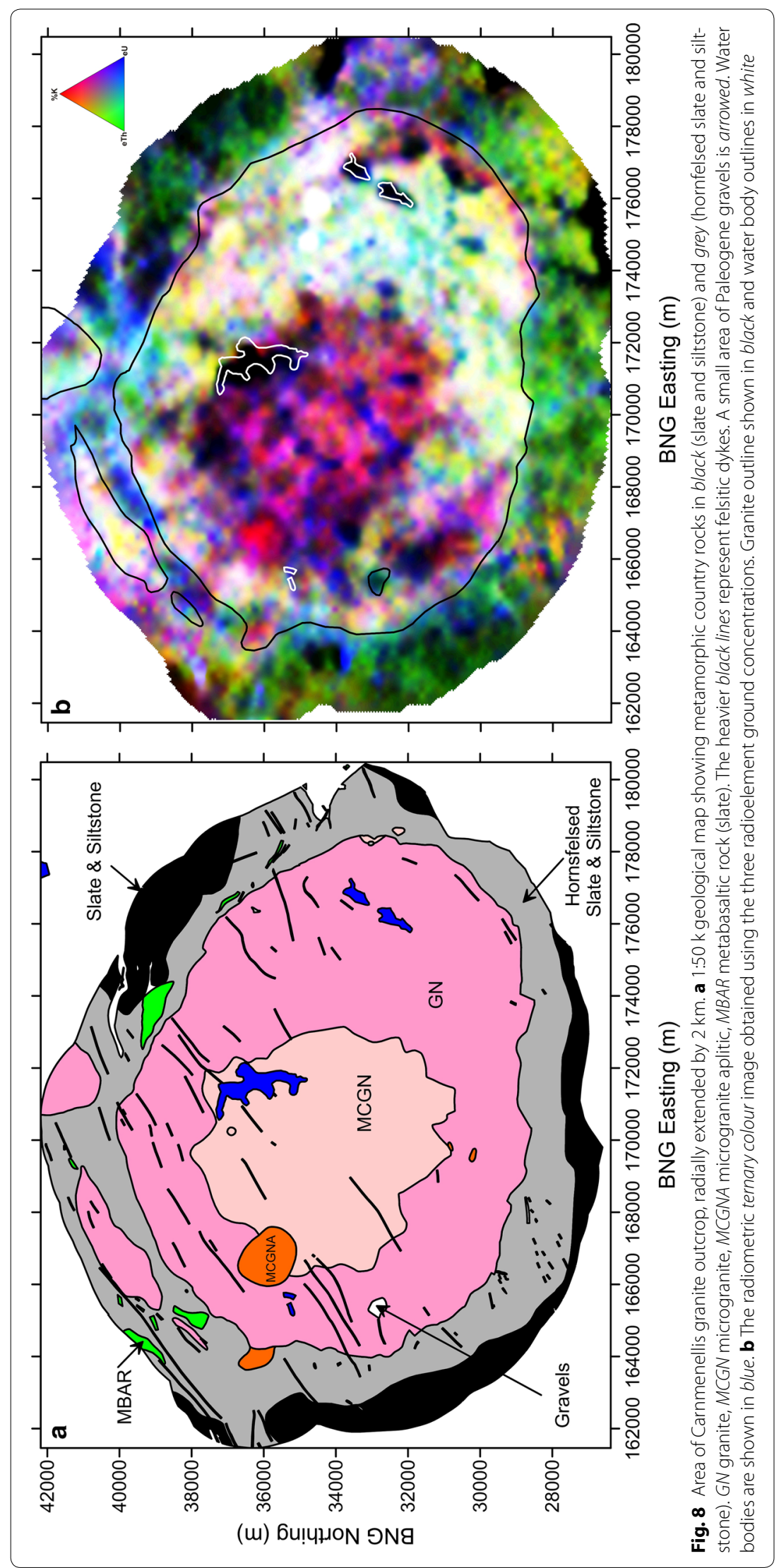


and the radionuclide spectral response using a radiometric ternary image. The rectangular area considered is $19 \times 15.8 \mathrm{~km}$. In Fig. 8a, the metamorphic country rocks are shown in black and grey. The granite lithologies are shown in brighter colours, with inland water bodies shown in blue. The heavier black lines represent felsitic dykes of Permian age ('elvan' dykes) which are steeply dipping and typically associated with the polymetallic mineralisation of the region (LeBoutillier 2003). The ternary radiometric response (Fig. 8b) isolates the granitic rock response from the country rocks and also identifies the three lithologies (GN, MCGN and MCGNA) defining the granite. Within this framework, more detailed variations are observed with black zones (low responses) associated with coastal and inland water bodies. One of the more interesting features is the central quasi-linear zones of higher uranium content which show the same trends as the elvan dykes. It is likely that these features are associated with mobilised uranium concentrations adjacent to fractures (Miller et al. 2001).

The corrected heat production values for the same area are shown in Fig. 9 which also incorporates the $\mathrm{BH}$ locations and heat production estimates from Table 1 for comparison. The application of the two density correction factors (on- and off-granite) has generated an offset along the granite outcrop (shown by a black line). The BH heat production values (Table 1) are shown as spot values and the corrections applied to the airborne data have improved the general correspondence between the two sets of estimates. When discussing the BH results across this granite, Wheildon et al. (1981) noted that heat production within the outcrop is highest near the granite/country rock contact and decreases towards the centre of the outcrop. The same conclusion is drawn here

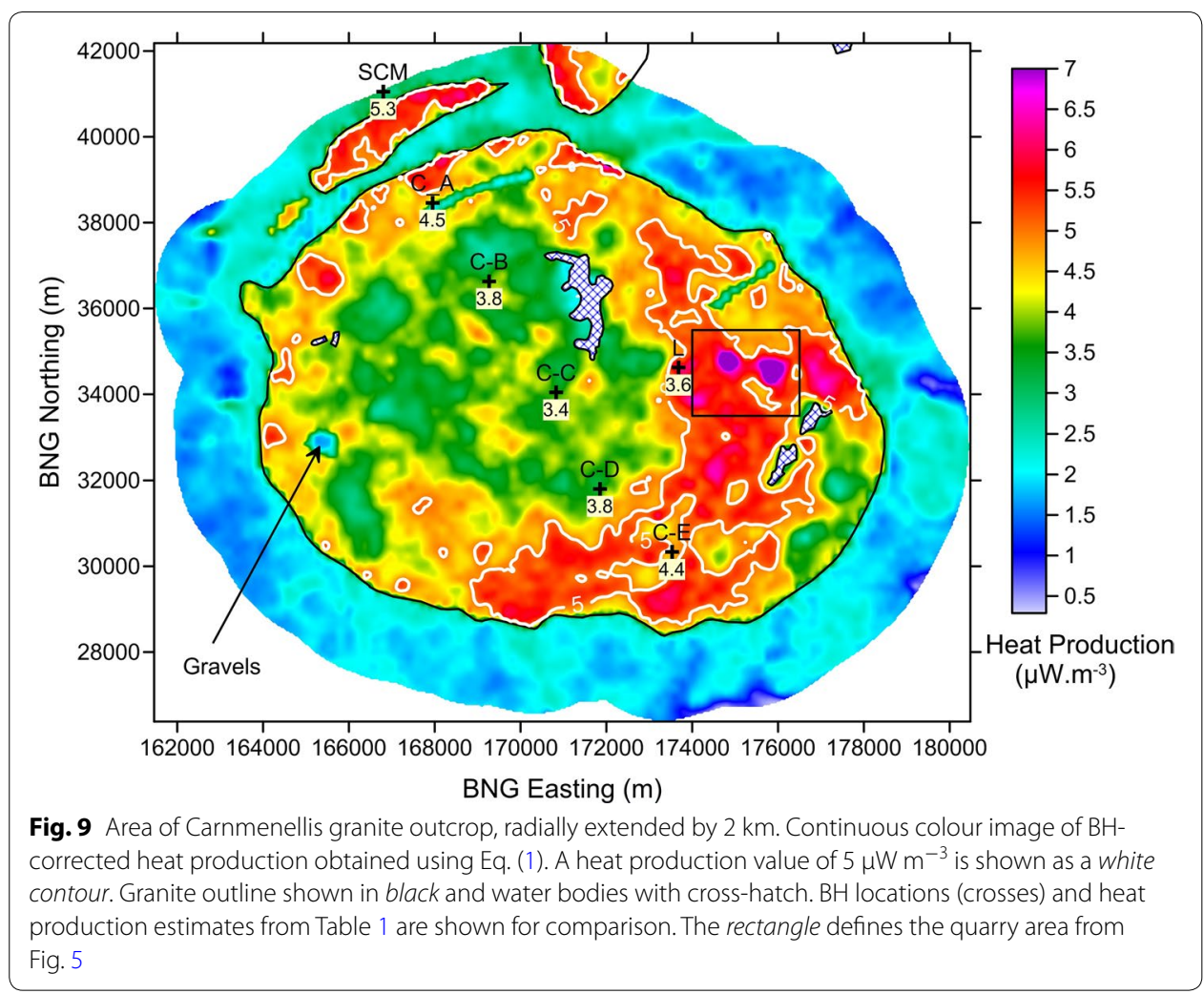


but the airborne estimates appear to provide additional resolution as shown by the areas with heat production $>5 \mu \mathrm{W} \mathrm{m}{ }^{-3}$. One such large zone in the $\mathrm{SE}$ is internal to the outcrop and not associated with the margin.

Although the airborne heat production values are obtained at a grid cell size of $40 \mathrm{~m}$, this apparent resolution cannot be relied on to provide a consistent set of bedrock heat production values. The resolution does however allow many of the near-surface perturbations to be identified and potentially rejected. Water bodies are readily identified but a small Palaeogene gravel deposit (arrowed) also provides a localised low. The rectangular study area (containing quarries) used in Fig. 5 is also shown. The no (or thin) soil areas clearly provide localised high values that perturb the radionuclide bedrock variations. All such localised variations require careful scrutiny to identify thin or absent soils.

With the above caveats in place, the heat production values across the remaining four granites are summarised in a similar manner to that of the Carnmenellis granite. Figure 10 shows the results using a common colour scale but at different mapping scales. All the highest heat production areas are contained within the outcrops and a contour of $5 \mu \mathrm{W} \mathrm{m}{ }^{-3}$ is shown as a reference. In the case of the Bodmin granite (Fig. 10c), the previously noted internal edge within the outcrop also generates high values. Since blanket bog is associated with the high moorlands of the Bodmin and Dartmoor granites, the

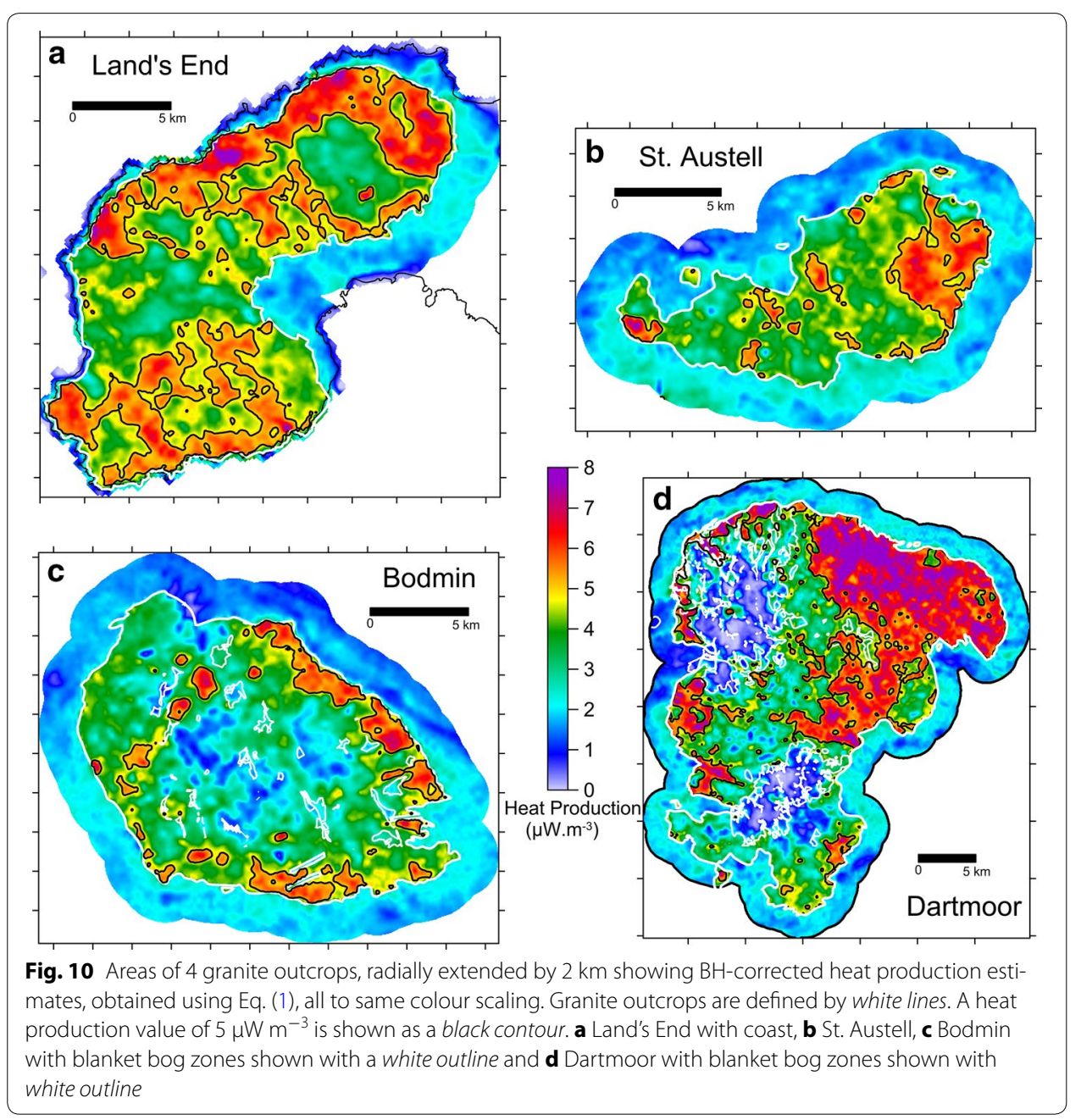


Table 2 Summary of high heat production (HP) by area across five granite outcrops using two thresholds of heat production

\begin{tabular}{|c|c|c|c|c|}
\hline Granite & $\begin{array}{l}\text { Outcrop area } \\
\left(\mathrm{km}^{2}\right)\end{array}$ & $\begin{array}{l}\text { Area } \\
\text { with } \mathrm{HP}>5 \mu \mathrm{W} \mathrm{m}{ }^{-3} \\
\left(\mathrm{~km}^{2}\right)\end{array}$ & 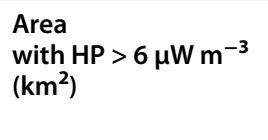 & $\begin{array}{l}\% \text { of total } \\
\text { outcrop area } \\
\text { with } \mathrm{HP}>6 \mu \mathrm{W} \mathrm{m}{ }^{-3} \\
\text { (\%) }\end{array}$ \\
\hline Land's End & 180.69 & 72.32 & 16.33 & 9 \\
\hline Carnmenellis & 138.53 & 32.34 & 1.83 & 1 \\
\hline St. Austell & 91.27 & 21.42 & 4.63 & 5 \\
\hline Bodmin & 203.16 & 25.85 & 4.32 & 2 \\
\hline Dartmoor & 624.58 & 225.62 & 137.53 & 22 \\
\hline
\end{tabular}

bogs are identified in Fig. 10c, d. In order to summarise the high heat production levels across all five granites, we take threshold values of 5 and $6 \mu \mathrm{W} \mathrm{m} \mathrm{m}^{-3}$ and calculate the areas within each outcrop providing these levels. The results are provided in Table 2. As is also evident in Fig. 10, the Dartmoor and Land's End granite appear to offer the greatest spatial potential in terms of their intrinsic radionuclide concentrations and associated heat production.

\section{District- scale heat production}

Deep geothermal heat, considered as a resource, has the potential to be utilised within urban areas where the energy consumers are concentrated. Airborne geophysical measurements are unusual in that they are obtained over such centres. At this more local urban scale of heat production evaluation, it is possible to exploit the uniform coverage of the airborne survey data to provide city and town estimates. Survey altitudes over urban areas are typically $>180 \mathrm{~m}$ due to regulatory restrictions (Beamish and White 2014). The standard processing applied to the radiometric data includes a correction for height. The main effect of increasing height is an increase in the spatial footprint of the sensor thus lowering spatial resolution. The procedure used a spatial database of defined urban areas (polygons); here we use a set of 28 conurbations across the survey area which range in population from 256,000 (Plymouth) to 15,000 (Saltash). The majority of the surface area associated with conurbations may be assumed to be artificial and therefore distinct from the soil and superficial (where present) deposits that characterise much of the rural landscape. In terms of their radiometric flux characteristics however, the urban centres appear to be equivalent to their immediate surroundings. As an example, the average Total Count measure of flux obtained from the 28 urban centres considered here $\left(143 \mathrm{~km}^{2}\right)$ is $1450 \mathrm{cps}$. The corresponding figure obtained from the set of annuli extending $1 \mathrm{~km}$ from each urban polygon (and excluding the conurbation polygon) is 1468 cps.

A statistical analysis of urban heat production estimates is summarised in the boxwhisker plot of Fig. 11 with the results arranged in order of decreasing size of area. The whole set of estimates (ALL URBAN) is shown as a final box. The interquartile range of the data is identified by the box with the median shown as a line within the box. The vertical lines with bars then define the range of the data. Obviously, the amplitudes observed are determined by local attributes of the underlying bedrock so that locations 


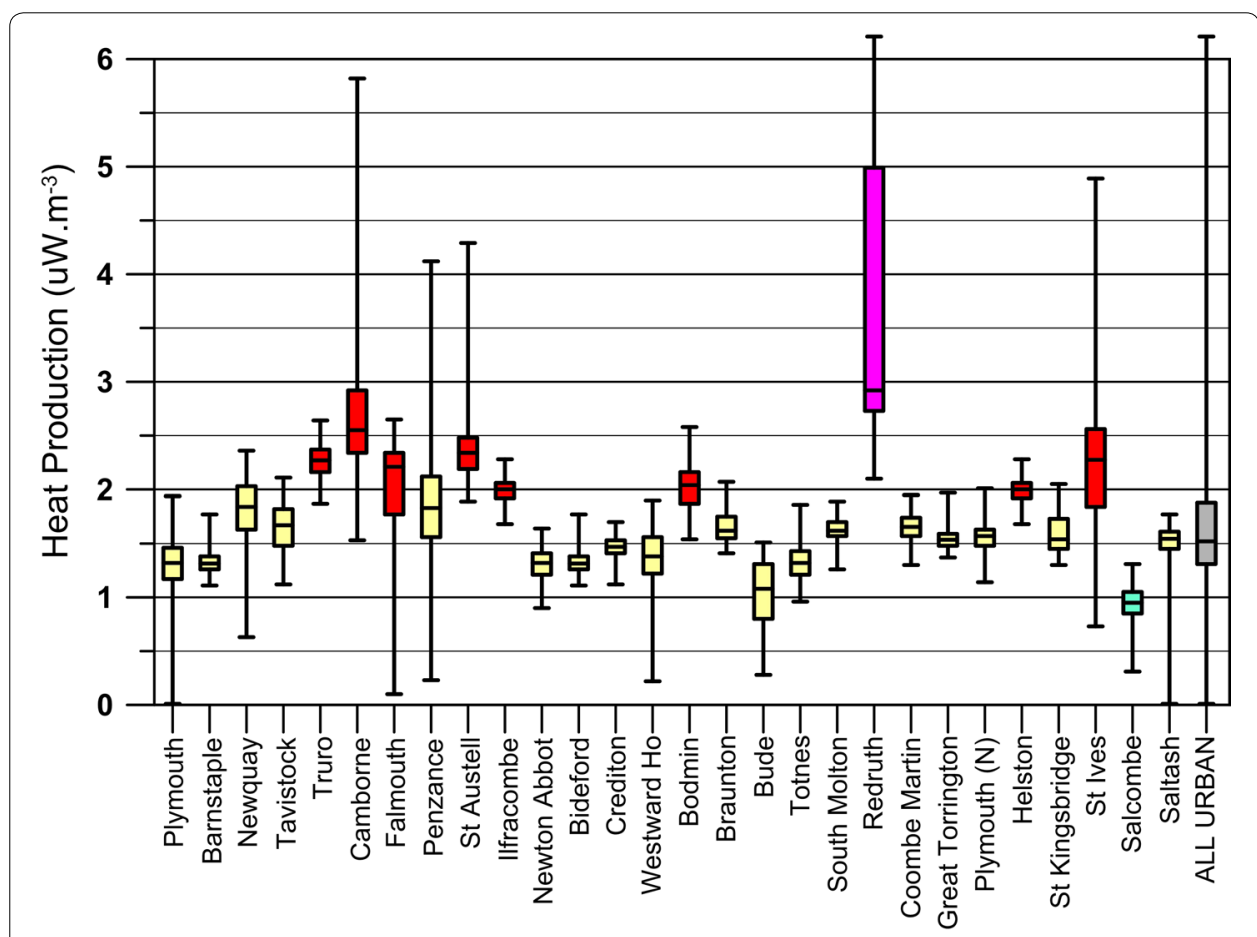

Fig. 11 Box-whisker plot of the BH-corrected heat production statistics over urban locations, arranged in the order of decreasing population size of each location. The final box summarises the complete (all-urban) data set. The locations of the five towns with the highest heat production values are shown in Fig. 3

associated with granitic terrain generate the largest medians and highest value tails. Within this framework, we can therefore identify the towns of Camborne, Penzance, St. Austell, Redruth and St Ives as having relatively high values (e.g. $>4 \mu \mathrm{W} \mathrm{m}{ }^{-3}$ ) within their urban perimeters. The locations of these towns are shown in Fig. 3.

\section{Discussion and conclusions}

Existing published BH heat flow measurements from SW England (across five granite outcrops and the country rocks) have been revised using a rigorous palaeoclimate correction scheme. Granite-average increases in heat flow over previously reported values of between $5.5 \%$ (St. Austell granite) and 9.4\% (Carnmenellis granite) were estimated. Predicted temperatures at a depth of $5 \mathrm{~km}$ largely exceed $200{ }^{\circ} \mathrm{C}$ and are $6-11 \%$ higher than previously estimated values. The revised granite-average temperatures at $5 \mathrm{~km}$ depth are $200{ }^{\circ} \mathrm{C}$ (Bodmin), $200{ }^{\circ} \mathrm{C}$ (Carnmenellis), $185^{\circ} \mathrm{C}$ (Dartmoor), $206{ }^{\circ} \mathrm{C}$ (Land's End) and $221^{\circ} \mathrm{C}$ (St. Austell).

The $\mathrm{BH}$ heat production values from the same published data were then used as a control when evaluating the heat production values obtained, at high spatial resolution, from a recent airborne radiometric survey of the region. The airborne radionuclide concentrations are obtained from the near surface $(50-60 \mathrm{~cm})$ and are therefore estimated largely within the soil profile. They are subject to a variety of soil and near-surface effects (e.g. flux attenuation) connected to soil density and wetness. In order to uniformly minimise the near-surface soil flux attenuation effects, we have demonstrated that increasing the airborne radionuclide concentration estimates by a factor of two is an appropriate, 
but not exact, simplification. These revised estimates show a partial correlation with the deeper BH data set at both off- and on-granite locations, and we use the BH data as control to correct the airborne estimates. We have found it necessary to apply different correction formulae to the on- and off-granite locations.

The corrected airborne heat production estimates are capable of identifying zones of high heat production at a detailed scale (e.g. 1:50k). Near-surface and spatially localised artefacts remain in the data and it is necessary to examine the high-resolution estimates using supplementary map and land-use data. Previously, using the sparse BH data, it was noted that heat production within the granite outcrops appeared larger towards the granite/country rock contact. Here we have quantified the detailed spatial distribution of heat production and defined clear zones with the highest values (e.g. $>5 \mu \mathrm{W} \mathrm{m}{ }^{-3}$ ). Although such zones have associations with the granite margins, they extend across significant areas of each granite, particularly in the case of the Land's End and Dartmoor granites. The SW area is well known for its magmatic-hydrothermal mineralisation associated with multi-phase granite emplacement. The locations of mineral concentrations (including radionuclides) generated by hydrothermal systems are discussed by Dines (1956). In many cases, the minerals concentrate towards the margins of the granites and cupolas (although not universally) and this appears to be reflected in the patterns of enhanced heat production.

Both shallow and deep geothermal heat can be considered as a potential energy resource. High heat production has the potential to be utilised within district-scale (heat-only) schemes either in the absence of, or alongside, electricity generation (Adkins 2013). Since the airborne data are uniformly acquired over urban districts, these data were analysed to provide an urban heat production assessment. The analysis indicates that the towns of Camborne, Penzance, St. Austell, Redruth and St Ives have relatively high values within their urban perimeters.

\section{Authors' contributions}

JB revisited the existing borehole heat production and heat flow data for SW England. He also conducted the heat flow calculations and provided the revised heat flow data. DB revisited the existing borehole heat production data and was responsible for the estimation of heat production estimates obtained from the airborne radiometric survey data and the correlations between the two. Both authors read and approved the final manuscript.

\section{Acknowledgements}

Our thanks go to Chris Yeomans for an internal review and to three reviewers for comments that improved the original submission. Topographic map data (Fig. 5) are based upon Ordnance Survey data with the permission of the Controller of Her Majesty's Stationery Office, ( $\odot$ Crown copyright. This paper is published with the permission of the Executive Director, British Geological Survey (NERC).

\section{Competing interests}

The authors declare that they have no competing interests.

Received: 22 January 2016 Accepted: 14 March 2016

Published online: 24 March 2016

\footnotetext{
References

Abraham EM, Lawal KM, Ekwe AC, Alile O, Murana KA, Lawal AA. Spectral analysis of aeromagnetic data for geothermal energy investigation of Ikogosi Warm Spring-Ekiti State, southwestern Nigeria. Geotherm Energy. 2014;2:6.

Adkins. Deep geothermal review study. Final report, Department of Energy and Climate Change (DECC); 2013. p. 1-142.

Baillieux P, Schill E, Abdelfettah Y, Dezayes C. Possible natural fluid pathways from gravity pseudo-tomography in the geothermal fields of Northern Alsace (Upper Rhine Graben). Geotherm Energy. 2014;2:16.

Barker JA, Downing RA, Gray DA, Findlay J, Kellaway GA, Parker RH, Rollin K. Hydrogeothermal studies in the United Kingdom. Q J Eng Geol Hydrogeol. 2000;33:41-58.
} 
Beamish D, Young ML. The geophysics of Northern Ireland: the Tellus effect. First Break. 2009;27:43-9.

Beamish D. Gamma ray attenuation in the soils of Northern Ireland, with special reference to peat. J Environ Radioact. 2013;115:13-27.

Beamish D. Environmental radioactivity in the UK: the airborne geophysical view of dose rate estimates. J Environ Radioact. 2014a;38:249-63.

Beamish D. Peat mapping associations of airborne radiometric survey data. Remote Sens. 2014b;6:521-39.

Beamish D. Relationships between gamma-ray attenuation and soils in SW England. Geoderma. 2015;259-260:174-86.

Beamish D, White J. TellusSW: airborne geophysical data and processing report. British Geological Survey Open Report, OR/14/014. 2014

Beardsmore GR, Cull JR. Crustal heat flow: a guide to measurement and modelling. Cambridge: Cambridge University Press; 2001.

Beck AE. Climatically perturbed temperature gradients and their effect on regional and continental heat-flow means. Tectonophysics. 1977:41:17-39.

Brady RJ, Ducea MN, Kidder SB, Saleeby JB. The distribution of radiogenic heat production as a function of depth in the Sierra Nevada Batholith. Calif Lithos. 2006:86:229-44.

Bodorkos S, Sandiford M, Minty BRS, Blewett RS. A high-resolution, calibrated airborne radiometric dataset applied to the estimation of crustal heat production in the Archaean northern Pilbara Craton, Western Australia. Precambrian Res. 2004;128:57-82.

Busby JP, Lee JR, Kender S, Williamson P, Norris S. Regional modelling of permafrost thicknesses over the past 130 ka: implications for permafrost development in Great Britain. Boreas. 2016:45(1):46-60.

Dines HG. The metalliferous mining region of south-west England. Memoir of the Geological Survey of Great Britain, HMSO, London; 1956.

Downing RA, Gray DA (editors). Geothermal energy — the potential in the United Kingdom. HMSO, London; 1986.

Downing RA, Gray DA. Geothermal resources of the United Kingdom. J Geol Soc. 1986b;143:499-507.

Grasty RL. Radon emanation and soil moisture effects on airborne gamma ray measurements. Geophysics. 1997:62:1379-85.

Grasty RL, Minty BRS. A guide to the technical specifications for airborne gamma-ray surveys. AGSO Australian Geological Survey Organisation. 1995; Record 1996/60.

IAEA. Airborne gamma ray spectrometer surveying. International Atomic Energy Agency, Vienna. 1991. Technical Report Series; No. 323.

IAEA. Guidelines for radioelement mapping using gamma ray spectrometry. International Atomic Energy Agency, Vienna. 2003. Technical Report Series; No. 136.

IAEA. Radioelement mapping. International Atomic Energy Agency, Vienna. 2010. Nuclear Energy Series; No. NF-T-1.3.

Jessop AM. Thermal geophysics. Developments in Solid Earth Geophys. 1990;1990(17):1-306.

Kock P, Samuelsson C. Comparison of airborne and terrestrial gamma spectrometry measurements-evaluation of three areas in southern Sweden. J Environ Radioact. 2011;102:605-13.

Lachenbruch AH. Crustal temperature and heat production: implications of the linear heat-flow relation. J Geophys Res. 1970;75:3291-300.

Le Boutillier NG. The tectonics of Variscan magmatism and mineralisation in South West England. Ph.D. thesis, University of Exeter, UK. 2003.

Lee MK. Hot dry rock. In: Geothermal energy_the potential in the United Kingdom. 1986; HMSO, London. p. $21-41$.

Lee MK, Brown GC, Webb PC, Wheildon J, Rollin KE. Heat flow, heat production and thermo-tectonic setting in mainland UK. J Geol Soc. 1987;144:35-42.

Leveridge BE, Hartley AJ. The Variscan Orogeny: the development and deformation of Devonian/Carboniferous basins in SW England and South Wales. In: The Geology of England and Wales, 2nd ed. Geological Society, London. 2006; p. $225-255$.

Løvborg L. The calibration of portable and airborne gamma-ray spectrometers-theory, problems and facilities. Ris $\varnothing$ Report M-2456. 1984; p. 1-207.

Maystrenko YP, Elevbakk KH, Ganerød GV, Lutro O, Olesen O, Rønning JS. 2D structural and thermal models in south-eastern Norway based on the recently drilled Årvollskogen borehole and 2D density, magnetic and thermal modelling. Geotherm Energy. 2014;2:15.

Middleton MF. Radiogenic heat generation in the Darling Range, Western Australia. Explor Geophys. 2013;44:206-14.

Miller WM, Alexander WR, Chapman NA, McKinley IG, Smellie JAT. Geological disposal of radioactive wastes and natural analogues. Oxford: Pergamon Press; 2001. p. 1-316.

Minty BRS. Fundamentals of airborne gamma-ray spectrometry. J Aust Geol Geophys. 1967;17:39-50.

Phaneuf C, Mareschal JC. Estimating concentrations of heat producing elements in the crust near the Sudbury Neutrino Observatory, Ontario, Canada. Tectonophysics. 2014;622:135-44.

Pitkin JA, Duval JS. Design parameters for aerial gamma ray surveys. Geophysics. 1980;1980(45):1427-39.

Richardson SW, Oxburgh ER. The heat flow field in mainland UK. Nature. 1979;282:565-7.

Richards HG, Willis-Richards J, Pye J. A review of geological investigations associated with the UK hot dry rock programme. Proc Ussher Soc. 1991;7:321-6.

Rybach L. Warmeproduktionsbestimmungen an Gestein der Schweizer Alpen. Beitr. Geol. Schweiz, Geotechn. Ser., 51 Kummerly/Frey, Bern. 1973; p. 1-43.

Rybach L. Radioactive heat production; a physical property determined by the chemistry of rocks. In: The physics and chemistry of minerals and rocks. Wiley, London. 1976; p. 309-18.

Rybach L. Determination of Heat Production Rate. In: Handbook of Terrestrial Heat Flow Density Determination. Kluwer, Dordrecht. 1988; p. 125-142.

Sams MS, Thomas-Betts A. 3-D numerical modelling of the conductive heat flow of SW England. Geophys J. 1988:92:323-34.

Tammemagi HY, Wheildon J. Terrestrial heat flow and heat generation in south-west England. Geophys J R Astron Soc. 1974;1974(38):83-94. 
Thomas-Betts A, Wheildon J, Sams MS. Further heatflow measurement and geothermal modelling in the vicinity of Carnmenellis granite. CSM Geothermal Energy Project. Report ETSU-G-137-P16, 1989; p. 1-113.

Tombs JMC. A study of the space form of the Cornubian granite batholith and its application to detailed gravity surveys in Cornwall. Mineral Reconnaissance Programme, Report No. 11. Inst Geol Sci. 1977;1977:1-5.

Westaway R, Younger PL. Accounting for palaeoclimate and topography: a rigorous approach to correction of the British geothermal dataset. Geothermics. 2013;48:31-51.

Wheildon J, Francis MF, Ellis JRL, Thomas-Betts A. Investigation of the SW England thermal anomaly zone. CEC Final Report, Contract No 097-76 EGUK, 568-78-1 EGUK. 1981; p. 1-410.

Wheildon J, Rollin KE. 1986. Heat Flow 8-20. In: Geothermal energy—-the potential in the United Kingdom. HMSO, London.1986; p. 8-20.

Willis-Richards J. Three-dimensional modelling from gravity of the Carnmenellis granite pluton, West Cornwall (Abstract of paper presented at the Tenth UK Geophysical Assembly). Geophys J R Astron Soc. 1986;74:251.

Willis-Richards J. Thermotectonics of the Cornubian batholith and their economic significance. Ph.D. thesis, Camborne School of Mines, UK. 1990.

\section{Submit your manuscript to a SpringerOpen ${ }^{\circ}$ journal and benefit from:}

- Convenient online submission

- Rigorous peer review

- Immediate publication on acceptance

- Open access: articles freely available online

- High visibility within the field

- Retaining the copyright to your article

Submit your next manuscript at $\boldsymbol{\nabla}$ springeropen.com 